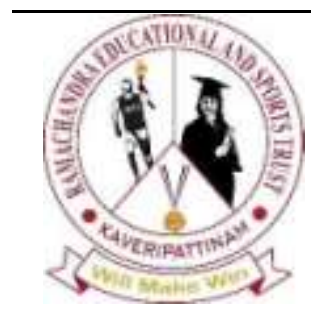

Contemporaneity of Language and Literature in the Robotized Millennium Vol: 3(1), 2021

REST Publisher

ISBN: 978-81-936097-3-6

Website: http://restpublisher.com/book-series/cllrm/

\title{
Inequality in Equality: A Satirical Construing of George Orewell's Allegorical Novella Animal Farm
}

\author{
J. Keba Immanuvel \\ Arul Anandar College (Autonomous), Karumathur, Madurai, Tamil Nadu, India.
}

Communism dwells in the idea of equality, liberty and socialism. It is a political, economic and socio economic revolution being stressed by its believers. Communist Manifesto is the bible of the communists written by Karl Marx, a Jewish philosopher, revolutionist and a visionary. Following the communist ideologies, Lenin and Stalin of Russia were able to expel the tyrant Nicholas II. With the rise of communism through Lenin, Stalin and other comrades, communism came to be noticed as a necessity ideology that could shape the human beings into being humans. At the beginning, Stalin gave an admirable administration, but later on he became like every other political leaders who had no differences in treating people equal. Stalin's downfall began when he misused the guidelines of the communism. After sometimes, the so called communist fort Russia threw away the tyrant Stalin and turned back to democracy. Based on this historical background, George Orwell (Eric Arthur Blair) an Indian born English writer, novelist, journalist, essayist and a critic wrote a novella Animal Farm in 1945 which remains still an oden read novella. George Orwell's writings echo the themes like political allegory, satire, nationalism, capitalism, political dishonesty, power, totalitarianism etc., Orwell's yet another masterpiece 1984 is a dystopian novel that soothsaid what would happen in 1984. In this novel, Orwell depicted how powerful leaders would rule the world wherein the powerless would remain as slaves of the powerful. In the novel 1984 Orwell quotes, Who controls the past controls the future. Who controls the present controls the past.(1984) This famous quotations is almost the central theme of the novel. 1984 is a typical example of George Orwell's caliber in handling the above mentioned themes. Animal Farm is a political satire which exposes the Russian revolution took place in 1917. The novel is written to tell the world what would happen when an ideologist politician fails to implement his ideas. This novella satirizes the rise and fall of communism in Russia. It also explores the vices of the Russian policies at the time of Stalin's rule. Orwell used animals in place of human beings. The plot of the novel is that how the animals in Manor Farm were treated miserably by Mr. Jones, the owner of the farm and how the animals rebelled against him and expelled him out of the farm and made the farm their own. Mr. Jones being the owner of the farm was always mindful of the profit, money and income that came from the farm through the hard laboring of the animals. He was never bothered about the welfare, health and prosperity of the animals. Mr. Jones is portrayed as the political ruler and the animals are compared as working class people of any country. The actuality of political leaders and the working class is the same in any country. Revolution is possible in many ways like protest, fight, starving, rebelling, avoid, writing, boycotting etc., The animals in the Manor Farm took rebelling as their weapon to bring down Mr. Jones, the owner. One fine day (bad day for Mr. Jones) Mr. Jones as usual left his farm under the care of his servants. Major is an old boar and the master (Lenin) arranged for a secret meeting for the animals and was able to inspire the animals to rebel against Mr. Jones. In that particular secret meeting, Major explained his long time vision and a dream he had recently. The core point of that meeting was to find out a solution that would cure their misery in the farm. Major spelt the how the animals in the farms of England suffered and man or men thoroughly the fruit of hard work.The Major addressed all other animals as comrades. This very word itself is a kind of vision of equality and equity. His explanation about their miserable life opened the eyes of all other animals in the farm. The Major says, "Now, comrades what is the nature of this life of ours? Let us face it, our lives are miserable, laborious and short... No animal in England knows the meaning of happiness or leisure..... No animal in England is free. The life of an animal is misery and slavery: that is the plain truth" (AF, 3 The Major continued to make them realize their pathetic condition in the farm. He also suggested the remedy for their worst condition. He says, “...Man is the only real enemy we have. Remove man from the scene, and the root cause of our hunger and over work is abolished forever"(AF, 4) This depiction of the animals' condition by the old Boar was accepted by all animals present and they were all ready for the rebellious war against Mr. Jones and to throw him out of the farm. After sometimes, the old Major died but the fire which he had given to the animals to revolutionize against their master. As usual, Mr. Jones left the farm under the care of his servants and the servants did not feed the animals properly that made the animals rebellious and angry. All animals came out of their sheds by breaking them. Mr. Jones and his servants were mystified with the strange and abnormal behavior of the animals. Jones along with his servants put their best efforts to control and to pacify the animals which resulted to failure. At the end of this fight, Mr. Jones and the servants were expelled from the farm. First time in the history animals had become the owners of a farm. The animals destroyed all the traces of Jones as they did not want any of the traces to remind anything about Mr. Jones. They sang their anthem 'Beasts of England' as a celebration of their victory. They animals were happy with their efforts in casting out the owner. They even changed the name of the farm as 'Animal Farm' from 'Manor Farm'. The pigs had learned to read and to write. They revealed this truth to the other animals that they had been teaching themselves from an old spelling book which belonged to Jones. This helped them change the name of the 
farm by themselves. The knowledge they had acquired kindled them to prepare seven important commandments which all had to be very strictly followed by the animals. The commandments run thus:

\section{The Seven Commandments}

1. Whatever goes upon two leg is an enemy.

2. Whatever goes upon four legs, or has wings, is a friend.

3. No animal shall wear clothes.

4. No animal shall sleep in abed.

5. No animal shall drink alcohol.

6. No animal shall kill any other animal.

7. All animals are equal. (AF, 15)

Though there were countable mistakes, they were well written. All the above said commandments were unanimously accepted by the animals without any fuss or argument. These commandments were considered as Ten Commandments given to the Israelites through Moses by God. After the revolution, the animals in the farm were happy, and friendly with each other. They accepted the Napoleon and Snowball, the cleverest pigs as their leaders. Mr.Jones, wanted to recapture his farm again from the animals. He with some of his friends attacked the animals, but the animals stood together and stronger and they defeated Jones once again from the farm. As time passed by, Snowball and Napoleon, the wisest pigs had differences of opinion. They could not travel together as they used to do in past. Totally Napoleon stood against the decisions of Snowball. Snowball had a vision of erecting a wind mill to educate all animals. Napoleon was not pleased with this idea and he did not want other animals to become educated. He, very tactfully drove away Snowball out of the farm and deceitfully declared that Snowball was a traitor and he could not be believed again. Later, Napoleon began the work of building a windmill with cooperation of all other animals. They worked without any struggle or blog in their mind. As the work was on process, slowly the Pigs started to violate the rules. They gradually became the supervisors for other animals. This attitude made the other animals to doubt the privileged pigs. Whenever the animals doubted about the activities of the pigs, Squealer stood there to convince the animals. Squealer had the tactics of changing the mindset of the animals by telling that the pigs did all the brain works so far and they had to be given advantages and privileges. Right from the beginning, the pigs were portrayed as superior thinkers. This readymade mindset made the animals to satisfy themselves with what was going around them. The animals who never wanted their freedom to be plucked out simply accepted the drudgery quietly. Even when the animals tried to oppose Napoleon, they were threatened by the dogs who stood as Napoleon's bodyguards. After two vain attempts, the windmill was in construction for the third time. Boxer, during the reconstruction of the windmill for the third time got injured and he could not be recovered from his injuries. This resulted to throw him away to the butchery house. Napoleon became the dictator in the farm through his vice moves and cruel thinking. The downfall of the animal farm started from Napoleon who slowly began to have contact with the neighbouring farms. Napoleon established his power with the help of Squealer. Napoleon violated the commandments made for them, made for them and made of them. Other pigs along with Napoleon started to drink alcohol. The pigs also started to walk in their hind legs (as human beings) with the whip in their hands to monitor and to supervise the animals. The commandments were modified as per the convenient of Napoleon and his followers. The modified commandments run thus, Four legs good, two legs better... All animals are equal But some animals are more equal Than other animals (af, 89 \& 90) The old animals (comrades) died one by one without knowing and understanding and the new animals did not know anything about their past (revolution). The name Animal Farm was changed and once again it was named as Manor Farm.At the end of the novella, George Orwell concludes that the remaining animals could not find any differences between pigs and human beings. The concluding lines of the novella run thus:"The creatures outside looked from pig to man, and from man to pig, and from pig to man again: but already it was impossible to say which was which"(AF,95) Any satire generally does the work of criticizing with an expectation to rectify the mistakes. Orwell treats Animal Farm differently. Though he satirizes, he brings out the reality of human beings. The animals presented in the novella are the great people who involved in the Russian Revolution. The resolution was possible with their dedication towards the mission, their thirst to transform their misery into happiness, their over laboring hours into leisurely hours, their sufferings into success. Karl Max's ideas shaped them to be different and to revolutionize. After the successful accomplishment of the revolutions, the leaders who motivated others slowly started to forget their responsibilities. They became victims of the worldly and humanly pleasures. They forgot their commandments. The animals (public) who believed them were treated more badly than their former rulers. The law makers became law breakers. The novella is completely a political parallel of the Russian history and Russian revolution. Mr. Jones, the owner of the farm symbolizes Nicholas II, the tyrant of Russia and the contemporary Lenin and Stalin. The Old boar, Major symbolizes Karl Marx, the great philosopher and the communist ideologist who induced the Russians to rebel

Just like Napoleon and Trotsky casted away Nicholas II, in the novella too, Napoleon and Snowball threw away Mr, Jones, the Farm owner. Squealer resembles Prava and Boxer is the Proletariat while the pigs represent the Bolsheviks. Mr. Pilkington and Mr. Fredrick who were the neighboring farmers represent Britain and Germany. The battle of Cowshed and the battle of Windmill denote to the two world wars. From the beginning to the end, the novella is presented as parallel of many incidents across the world. Karl Marx brought communism to make the world equal and common to all. His visions triumphed in Russia. For sometimes, the Russian people were treated equally. But slowly there were changes and modifications in equality. There started inequality in equality. Some were treated freely and many were treated more freely. Inequality in equality is never the actual equality which Karl Marx dreamt of. There is no mistake in Karl Marx and his ideologies. Implementing and execution of the ideologies made all the differences. A good law or principle alone cannot make great impacts and great changes. A loyal follower, a dedicated leader, a selfless thinker alone can implement 
such law or principle successfully and sustain for longer years unlike Russian revolution. Communist leaders failed in Russian and in other countries due to selfish and corrupted leaders but communism can never fail as long as there are thinking minds on the earth.

\section{References}

1. Orwell, George. Animal Farm. Penguin Books India Pvt.Ltd, 2011.Print.

2. Orwell, George. 1984. Fingerprint Classics, India, 2019.Print.

3. Waugh, Patricia. Literary Theory and Criticism. Oxford University Press, New Delhi.2006.Print.

4. Bounds, Philip (2009). Orwell and Marxism: The Political and Cultural Thinking of George Orwell. International Library of Cultural Studies. I.B.Tauris. ISBN 978184511 8075.

5. O'Neill, Terry, ed. Readings on Animal Farm. San Diego: Greenhaven Press, 1998.

6. https://en.wikipedia.org > wiki > Animal_Farm 